\title{
Confiabilidade da eficiência mastigatória com beads e correlação com a atividade muscular******
}

\author{
Reliability of masticatory efficiency with beads and correlation with \\ the muscle activity
}

\author{
Cláudia Maria de Felício* \\ Gisele Aparecida do Couto** \\ Cláudia Lúcia Pimenta Ferreira*** \\ Wilson Mestriner Junior****
}

*Fonoaudióloga. Professora Doutora do Departamento de Oftalmologia, Otorrinolaringologia e Cirurgia de Cabeça e Pescoço da Faculdade de Medicina de Ribeirão Preto da Universidade de São Paulo. Endereço para correspondência: Av. Bandeirantes, 3900 - Ribeirão Preto SP - CEP 14049-900 (cfelicio@fmrp.usp.br).

**Fonoaudióloga.

***Fonoaudióloga. Doutoranda em Ciências Médicas pelo Departamento de Oftalmologia, Otorrinolaringologia e Cirurgia de Cabeça e Pescoço da Faculdade de Medicina de Ribeirão Preto da Universidade de São Paulo.

****Cirurgião-Dentista. Professor Associado do Departamento de Clínica Infantil, Odontologia Preventiva e Social da Faculdade de Odontologia de Ribeirão Preto da Universidade de São Paulo.

******Trabalho Realizado na Faculdade de Medicina de Ribeirão Preto e Faculdade de Odontologia de Ribeirão Preto da Universidade de São Paulo.

Artigo Original de Pesquisa Artigo Submetido a Avaliação por Pares Conflito de Interesse: não

Recebido em 23.05.2008. Revisado em 02.08.2008; 23.08.2008; 03.10.2008.

Aceito para Publicação em 21.10.2008.

\begin{abstract}
Background: the use of the colorimetric method with beads to evaluate mastigatory efficiency may be promising, however no report is found about its reliability. Aim: to investigate the reliability of the beads to test masticatory efficiency and its correlation with the electromyographic activities of the anterior temporal and masseter muscles. Methods: participants of this study were nineteen young adults, nine males and ten females, aged eighteen to twenty-eight years, with full dentition, Angle class I, with no history of temporomandibular disorder, neurological or cognitive deficit, previous or current tumors or traumas in the head and neck region, and orthodontic treatment or orofacial myofunctional therapy. The masticatory efficiency test was performed using beads, fuchsine-containing granules, in the folowing conditions: habitual chewing, right and left unilateral chewing, for 20 seconds. Electromyographic recordings were obtained simultaneously. Also, the maximal clenching was registered. The amount of fuchsin released upon chewing was measured using a Beckman DU-7 UV-Visible Spectrophotometer (Beckman Inc., Palo Alto, CA, USA). Results: high reliability was observed for the masticatory efficiency test $(r=0.86, p<0.01)$ and correlation with the electromyographic activities $(r=0.76, p<0.01)$. Also, positive and significant correlations were observed when the conditions were separately analyzed. Conclusion: the masticatory efficiency test performed with beads proved to be a reliable method and positively correlated to the electromyographic activities of the anterior temporal and masseter muscles. Key Words: Mastication; Efficiency; Electromyography; Masticatory Muscles.
\end{abstract}

\section{Resumo}

Tema: a avaliação da eficiência mastigatória pela análise colorimétrica com beads, pode ser um método promissor, mas não há relatos sobre a sua confiabilidade. Objetivo: investigar a confiabiabilidade das beads para teste de eficiência mastigatória e a correlação com a atividade eletromiográfica dos músculos masseter e temporal anterior. Método: participaram dezenove sujeitos adultos jovens, nove do gênero masculino e dez do feminino com idades entre dezoito e vinte-oito anos, com dentição completa, sem histórico de desordem temporomandibular, trauma, cirurgia na região de cabeça e pescoço, tratamento ortodôntico ou fonoaudiológico. O teste de eficiência mastigatória foi realizado combeads nas condições: mastigação habitual, mastigação unilateral direita e esquerda, com duração de 20 segundos. Simultaneamente, foi realizada a eletromiografia. A atividade em máxima intercuspidação habitual dos dentes também foi registrada. A quantidade de fucsina liberada após a mastigação foi medida usando o espectrofotômetro Beckman DU-7 UV-Visible (Beckman Inc., Palo Alto, CA, USA). Resultados: houve alta confiabilidade do teste de eficiência mastigatória $(r=0,86, p<0,01)$ e correlação significante com a atividade eletromiográfica $(\mathrm{r}=0,76, \mathrm{p}<0,01)$. Também houve correlações positivas quando as provas foram analisadas separadamente. Conclusão: o teste de eficiência mastigatória realizado com beads mostrou-se um método confiável e correlacionado positivamente à atividade eletromiográfica dos músculos temporal anterior e músculos masseter.

Palavras-Chave: Mastigação; Eficiência; Eletromiografia; Músculos Mastigatórios.

Referenciar este material como:

A Felício CM, Couto GA, Ferreira CLP, Mestriner Jr.W. Reliability of masticatory efficiency with beads and correlation with the muscle activity (original title: E. Confiabilidade da eficiência mastigatória com beads e correlação com a atividade muscular). Pró-Fono Revista de Atualização Científica. 2008 out-dez;20(4):22530 . 


\section{Introduction}

Mastication is of interest to health professionals because it stimulates the growth, development and health maintenance of the stomatognathic system, because many patients present masticatory disorders, and also because it can be used as a therapeutic strategy in orofacial myofunctional disorders.

Several methods are used in research for the analysis of mastication, among them the masticatory efficiency (ME) test and electromyography (EMG). The concept of ME corresponds to the ability of degradation and the extent of trituration of food. Traditionally, natural foods are used in the ME test and the final product resulting from trituration is analyzed with the aid of sieves (1). The inconveniences of this procedure are variations of the food in question and partial food loss $(2,3)$.

ME can also be determined by colorimetry (4) using artificial test material whose standardization leads to more reliable result 5,6). Among them are beads developed in Brazil (7), although their reliability and correlation with another method have not been tested.

EMG has been extensively used in research, is considered to be a valid method for the assessment of masticatory muscle function (8-14) and has been correlated with masticatory efficiency (15-17).

The objective of the present study was to investigate the reliability of $\mathrm{ME}$, determined by means of the colorimetric method with beads, and the correlation with the electromyographic activities of the anterior temporal and masseter muscles.

\section{Method}

The study was approved by the Human Research Ethics Committee (HCFMRPUSP n ${ }^{\circ}$. 709/ 2007) and the subjects gave written informed consent to participate.

Nineteen young adults, 9 males and 10 females, aged 18 to 28 years (mean age $=22.9$ ) participated in the study, selected by clinical examination and interview.

Inclusion criteria: to present natural and full dentition or only the absence of the third molars, absence of caries and Angle class I occlusion upon clinical examination.

Exclusion criteria: to present dentofacial deformity, oral breathing, a history of surgery or traumas in the head and neck region, orthodontic treatment, myofunctional orofacial therapy or temporomandibular disorder symptoms, according to a previously tested protocol (18).

\section{Masticatory efficiency test}

For the ME test we used beads obtained by ionotropic gellification of an aqueous dispersion of $2 \%$ pectin containing $50 \%$ solids and fuchsin in a 1.0 $\mathrm{M}$ calcium chloride solution. After preparation, the beads were coated with a 5\% Eudragit solution (Eudragit E100) in a solvent mixture of $10 \%$ acetone in absolute ethanol. Next, $250 \mathrm{mg}$ of the beads were packed in polyvinyl acetate capsules with $0.67 \mathrm{~mm}$ thick walls, inner diameter of $7.6 \mathrm{~mm}$ and outer diameter of $8.95 \mathrm{~mm}$, and sealed (7).

The subjects were instructed to chew the beads in their free habitual manner. The test was stopped after 20 seconds and the beads were collected into a container identified with subject and test number. Mastication tests on the right and left were later carried out following the same procedures and simultaneously with EMG analysis of the musculature.

After mastication, the content of the capsule was dissolved in $5 \mathrm{ml}$ of water by mixing constantly for 30 seconds. The solution was then filtered through qualitative filter paper and the extracted dye was quantitated in nanometers $(\mathrm{nm})$ with a Beckman DU7 UV-Visible Spectrophotometer (Beckman Inc., Palo Alto, CA, USA). This permitted the determination of ME on the basis of the concentration of extracted fuchsin. The analyses were carried out at the Pharmacotechnique Laboratory of the Faculty of Pharmaceutical Sciences of Ribeirão Preto, University of São Paulo.

\section{Electromyographic Analysis}

The EMG was recorded using an eight-channel computerized surface electromyograph (Lynx Tecnologia Eletrônica -EMG1000). The subject's skin was cleaned with $70^{\circ} \mathrm{GL}$ alcohol to reduce the impedance between the skin and the electrode. disposable bipolar surface electrodes $(\mathrm{Ag} / \mathrm{AgCl}$, $42 \mathrm{~mm}$, Hal Industry and Commerce LTDA) were positioned in the direction of the fiber bundles of each masseter and temporal muscle. A reference electrode was placed on the patient's arm.

The Aqdados software (Lynx Tecnologia Eletrônica) was used for signal recording with a sampling frequency of $1 \mathrm{KHz}$, after the analogic EMG signal was digitally amplified and filtered to eliminate common interfering noise. The EMG signals were recorded and later calculated as muscle activity evaluated as root mean square 
(R.M.S.) of amplitude (?V) with the aid of the AqAnalysis software.

The EMG evaluation was done under the following clinical conditions:

. maximal voluntary dental clench in maximal habitual intercuspation (MHI) - the subject was invited to clench as hard as possible for $5 \mathrm{sec}$;

. free bead chewing (usual);

. bead chewing on the right side;

. bead chewing on the left side (20 sec.).

Two trials of each clinical condition were performed and the average muscle EMG activity (?V) was considered in each clinical condition. EMG recording was conducted in a calm and silent environment with low luminosity. The subject was seated on a comfortable chair with no headrest (office type), his feet resting on the floor, and arms resting on his lap. The head was positioned upright and the Frankfort posture/plan was used as a positioning parameter.

\section{Data Analysis}

The sample was analyzed in a descriptive manner using the means and standard deviations of ME values and of the EMG activity of the anterior masseter and temporal muscles. The reliability of the method was analyzed by the splithalf reliability test considering the masticatory $\mathrm{ME}$ tests (free beads, beads on the right and on the left) to be the first list of variables and the EMG tests (mastication of the beads and MIH) to be the second.

The correlations of EMG and ME activity in the corresponding tests, as well as the EMG in MHI and the ME tests, were calculated by the Pearson product-moment correlation test. The Statistica software was used for all calculations, with the level of significance set at $\mathrm{p}<0.05$.

\section{Results}

The reliability of $\mathrm{ME}$ in relation to $\mathrm{EMG}$, considering all tests jointly, was 0.86 and the total correlation was 0.76 . Table 1 lists the ME results for each subject based on colorimetric analysis, and the means and standard deviations for the sample. Table 2 lists the means and standard deviations of the EMG activity of the muscles studied.

There were positive and significant correlations between ME and EMG activity during free bead mastication, bead mastication on the right, bead mastication on the left and in MHI. The Pearson $r$ values and the levels of significance are given Table 3.

TABLE 1: Masticatory efficiency according to the concentration of the fuchsin dye $(\mu \mathrm{g} / \mathrm{ml})$

\begin{tabular}{llcl}
\hline & & Bead mastication & \\
\hline Subjects & Free & Right & Left \\
\hline 1 & 0.22 & 0.24 & 0.21 \\
2 & 0.23 & 0.23 & 0.30 \\
3 & 0.10 & 0.18 & 0.14 \\
4 & 0.18 & 0.14 & 0.32 \\
5 & 0.21 & 0.28 & 0.39 \\
6 & 0.19 & 0.27 & 0.42 \\
7 & 0.22 & 0.37 & 0.18 \\
8 & 0.23 & 0.16 & 0.28 \\
9 & 0.27 & 0.22 & 0.27 \\
10 & 0.23 & 0.30 & 0.26 \\
11 & 0.22 & 0.22 & 0.27 \\
12 & 0.27 & 0.27 & 0.36 \\
13 & 0.24 & 0.27 & 0.28 \\
14 & 0.38 & 0.40 & 0.36 \\
15 & 0.47 & 0.40 & 0.47 \\
16 & 0.32 & 0.33 & 0.35 \\
17 & 0.29 & 0.42 & 0.38 \\
18 & 0.16 & 0.29 & 0.29 \\
19 & 0.21 & 0.35 & 0.31 \\
Mean & 0.24 & 0.28 & 0.31 \\
SD & 0.08 & 0.08 & 0.08 \\
\hline
\end{tabular}

Test of free bead mastication, unilateral right mastication and unilateral left mastication. $\mathrm{SD}=$ standard deviation. 
TABLE 2. EMG activity of the muscles according to the test

\begin{tabular}{llllll}
\hline & & RT & LT & RM & LM \\
\hline MIH & Mean & 163.09 & 162.22 & 188.17 & 186.72 \\
& SD & 65.12 & 56.21 & 87.36 & 80.66 \\
\cline { 1 - 2 } Free beads & Mean & 81.96 & 86.18 & 92.91 & 96.63 \\
& SD & 32.71 & 28.61 & 42.68 & 36.55 \\
\cline { 1 - 1 } Beads on the right & Mean & 94.49 & 89.03 & 108.15 & 90.94 \\
& SD & 34.24 & 32.80 & 43.22 & 40.45 \\
\cline { 1 - 2 } Beads on the left & Mean & 86.30 & 99.10 & 97.91 & 119.53 \\
& SD & 32.83 & 35.05 & 44.27 & 40.94
\end{tabular}

$\mathrm{RT}=$ right temporal muscle, $\mathrm{LT}=$ left temporal muscle, $\mathrm{RM}=$ right masseter muscle , $\mathrm{LM}=$ left masseter muscle

TABLE 3. Correlations between EMG activity and masticatory efficiency

\begin{tabular}{|c|c|c|c|}
\hline & FBM & RBM & LBM \\
\hline EMGTD & $0.49^{*}$ & $0.66^{* *}$ & 0.81 *** \\
\hline EMGTE & $0.48^{*}$ & $0.72^{* * * *}$ & $0.59 * *$ \\
\hline EMGMD & $0.55^{*}$ & $0.52 *$ & 0.26 \\
\hline EMGME & $0.49^{*}$ & $0.80^{* * *}$ & 0.34 \\
\hline EMGMIHTD & $0.47^{*}$ & 0.42 & $0.67 * *$ \\
\hline EMGMIHTE & 0.45 & 0.36 & 0.28 \\
\hline EMGMIHMD & $0.59 * *$ & $0.49 *$ & 0.23 \\
\hline EMGMIHME & $0.57 *$ & $0.60 * *$ & 0.14 \\
\hline
\end{tabular}

\section{Discussion}

Masticatory performance is determined by different factors such as occlusion, bite force, muscular activity, and coordination of the masticatory muscles $(10,19)$. The type of food and its interaction with the saliva, teeth and biomechanical system can also influence mastication $(8,20)$.

A wide variety of foods have been used to analyze ME, among them natural foods $(1,3,8,17)$ and artificial materials based on silicone $(20,21)$. The subject is instructed not to swallow the material after trituration and the material is collected, passed through graded sieves and weighed. The greater the amount that passes through the finest sieve, the greater the $\mathrm{ME}(1,6)$.

Materials for the ME test that do not involve loss of part of the food by swallowing or typical variations of natural foods have been recently developed in Brazil, such as PVC capsule containing fuchsin violet granules (6) and beads (7). The degree of fragmentation of these materials is determined on the basis of fuchsin release by means of colorimetric analysis and on laboratory tests of resistance, absorbance and reproducibility $(6,7)$.

We did not detect studies determining the correlation of ME using beads and another method already accepted as valid for the analysis of performance of masticatory function. 
In the present study, EMG was chosen for the analyses of correlation between the ME test with beads and the reliability of the methods because it is a widely used and accepted method for the investigation of masticatory muscle function (8-9), permitting the characterization of functional problems, guiding prevention and rehabilitation actions in the speech therapy (22) and dentistry $(10,11,13)$ area, as well as favoring the analysis of the results of treatment $(12,14)$.

The results revealed positive correlations between ME and the EMG activity recorded during mastication and in MHI. Analysis of the tests as a whole revealed high reliability and correlation between the two methods. Thus, there is a direct relation between the activity produced by the muscles and bead fragmentation. This observation supports the reliability of the method for ME analysis, which could be used as a complementary or alternative method for the analysis of performance in trituration, reflecting the ability of the muscles to produce energy during masticatory function.

The present results agree with previous findings showing that ME and EMG activity are correlated when other artificial (15-16) and natural (17) foods are used.

In the near future, these low-cost beads could be produced on a large-scale basis by the pharmaceutical industry, permitting their clinical utilization (7). It is recommendable to test the reliability of the method in other samples and also in relation to other methods.

\section{Conclusion}

Based on the present results, it was possible to conclude that the colorimetric method with beads is reliable for the determination of masticatory efficiency and is highly correlated with the muscular activity recorded by electromyography.

\section{References}

1. Jiffry MTM. Variations in the particles produced at the end of mastication in subjects with different types of dentition. J Oral Rehabil 1983;10:357-62.

2. Peyron MA, Blanc O, Lund JP, Woda A. Influence of age on adaptability of human mastication. J Neurophysiol. 2004;92(2):773-9.

3. Frecka JM, Hollis JH, Mattes RD. Effects of appetite, BMI, food form and flavor on mastication: almonds as a test food. Eur J Clin Nutr. 2007;61(7):1-8.

4. Kayser AF, Van der Hoeven JS. Colorimetric determination of the mastigatory performance. J Oral Rehabil. 1977;4(2):145-8.

5. Mestriner Júnior W, Mazzetto MO, Felício CM, Freitas O, Spadaro, ACC. Comparação da eficiência mastigatória avaliada pelo uso de um método colorimétrico nas dentições decídua e permanente. Jornal Brasileiro de Ortodontia e Ortopedia Facial. 2005;10(57):242-8.

6. Escudeiro C, Freitas O, Spadaro ACC. Mestriner Júnior W. Development of a Colorimetric System for Evaluation of the Masticatory Efficiency. Braz Dent J. 2006;17:95-9.

7. Moreschi PE. Desenvolvimento e caracterização de micropartículas "beads" para avaliação da eficiência mastigatória [dissertação]. Ribeirão Preto: Faculdade de Ciências Farmacêuticas, Universidade de São Paulo; 2006.

8. Mioche L, Bourdiol P, Monier S, Martin JF, Cormier D. Changes in jaw muscles activity with age: effects on food bolus properties. Physiol Behav. 2004;82(4):621-7.
9. Peyron MA, Blanc O, Lund JP, Woda A. Influence of age on adaptability of human mastication. J Neurophysiol. 2004;92(2):773-9.

10. Ferrario VF, Tartaglia GM, Maglione M, Simion M, Sforza C. Neuromuscular coordination of masticatory muscles in subjects with two types of implant-supported prostheses. Clin Oral Implant Res. 2004;15(2):219-25.

11. Rodrigues AMM, Bérzin F, Siqueira VCV. Análise eletromiográfica dos músculos masseter e temporal na correção da mordida cruzada posterior. Revista Dental Press de Ortodontia e Ortopedia Facial. 2006;11(3):55-62.

12. Trawitzki LV, Dantas RO, Mello-Filho FV, Marques W Jr. Effect of treatment of dentofacial deformities on the electromyographic activity of masticatory muscles. J Oral Maxillofac Surg. 2006;35(2):170-3.

13. Cha BK, Kim CH, Baek SH. Skeletal sagittal and vertical facial types and electromyographic activity of the masticatory muscle. Angle Orthod. 2007;77:463-70.

14. Felício CM, Melchior MO, Ferreira CLP, Rodrigues da Silva MAM. Otologic symptoms of temporomandibular disorder and effect of orofacial myofunctional therapy. Cranio. 2008;26(2) "in press"

15. Wilding RJ, Shaikh M. Muscle activity and jaw movements as predictors of chewing performance. J Orofac Pain. 1997;11(1):24-36.

16. Weijnen FG, Van der Bilt A, Kuks JBM, Van der Glas HW. Oudenaarde I, Bosman F. Masticatory performance in patients with myasthenia gravis. Arch Oral Biol. 2002;47(5):393-8. 
17. Paphangkorakit J, Chaiyapanya N, Sriladlao P, Pimsupa S. Determination of chewing efficiency using muscle work. Arch Oral Biol. 2008 Feb 15.

18. Felicio CM, Mazzetto MO, Silva MAMR, Bataglion C, Hotta TH. A Preliminary Protocol for Multi-Professional Centers for the Determination of Signs and Symptoms of Temporomandibular Disorders. Cranio. 2006;24(4):258-63.

19. Piancino MG, Talpone F, Bole T, Castroflorio T, Torselho F, Debernardi C, Bracco P. Electromyographic evaluation of neuro muscular co-ordination during chewing in a subject with organic occlusion. Miinerva Stomatol. 2005;54(6):379-87.
20. Toro A, Buschang PH, Throckmorton G, Roldán S. Masticatory performance in children and adolescents with Class I and II malocclusions. Eur J Orthod. 2006;28(2):112-9.

21. Gavião MBD, Raymundo VG, Rentes AM. Masticatory performance and bite force in children with primary dentition. Braz Oral Res. 2007;21(2)146-52.

22. Bianchini EMG. Eletromiografia de superfície e eletrognatografia: aplicação clínica no campo da motricidade orofacial. Anais do XIII Congresso Brasileiro de Fonoaudiologia; 2005 Sept 28-30; Santos, Brazil. São Paulo: Sociedade Brasileira de Fonoaudiologia; 2005. 